Studi Kasus

\title{
Model Delone dan McLean Untuk Menguji Kesuksesan Aplikasi Mobile Penerimaan Mahasiswa Baru
}

\author{
Nani Agustina, Entin Sutinah \\ Program Studi Sistem Informasi, Universitas Bina Sarana Informatika, Jl.Kamal Raya No.18 Ringroad Barat, Cengkareng Jakarta Barat 11730, \\ Indonesia
}

\section{KEYWORDS}

Delone dan McLean, Kesuksesan Sistem Informasi, Aplikasi Mobile, Penerimaan Mahasiswa Baru

\section{CORRESPONDENCE}

Phone: +62 81210748205

E-mail: entin.esh@bsi.ac.id

\section{INTRODUCTION}

Penerimaan Mahasiswa Baru (PMB) kegiatan tahunan yang dilakukan oleh setiap Perguruan Tinggi, baik perguruan tinggi negeri maupun perguruan tinggi swasta. Bagi perguruan tinggi swasta penerimaan mahasiswa baru sangat diharapkan keberadaannya karena dengan semakin banyak menerima mahasiswa baru, dapat memperkuat eksistensi perguruan tinggi tersebut. Salah satunya Bina Sarana Informatika setiap tahunnya selalu menerima mahasiswa baru mulai dari penerimaan mahasiswa baru gelombang 1 sampai dengan 6 dimana kegiatan penerimaan siswa baru dilakukan dari bulan November sampai dengan September setiap tahunnya. Bina Sarana Informatika dalam proses penerimaan mahasiswa barunya menggunakan mobile aplikasi PMB yang dimana para calon mahasiswa harus mendownload aplikasi PMB tersebut di playstore. Sistem informasi yang diberi nama PMB BSI hanya bisa diakses melalui Android Smartphone.

\begin{abstract}
A B S T R A C T
Penerimaan Mahasiswa Baru (PMB) merupakan kegiatan wajib setiap tahun yang dilakukan oleh setiap Perguruan Tinggi, baik Pergurauan Tinggi Negeri maupun Perguruan Timggi Swasta. Segala informasi tentang kententuan pendaftaran, mengikuti ujian saringan, jadwa dalam sebuah aplikasi berbasis mobile dengan nama mobile aplikasi PMB BSI. 2017/2018. Perlunya pengukuran atas kesuksesan penerapan aplikasi tersebut seberapa efektif manfaatnya dalam menunjang pengolahan data pada proses penerimaan mahasiswa baru, maka dari itu penulis mencoba menggukur kesuksesan dari pengunaan aplikasi tersebut digunakan dalam pertanyaan. Berdasarkan hasil uji coba, diketahui bahwa aplikasi berbasis mobile PMB dilakukan dengan mahasiswa baru fakultas Ekonomi dan Bisnis yang terdiri dari 133 populasi, selanjutnya diambil 100 responden untuk diambil sebagai sample penelitan. litian ini penghitungan validitas semua variable semuanya valid dikarenakan semuanya lebih besar dari $r$ tabel $=0,195$. Selanjutnya untuk perhitungan reliabelitas sebanyak 0,917 , sehingga dengan kondisi seperti ini maka aplikasi mobile PMB sudah dapat dipercaya dalam tingkat sistem dan informasi.
\end{abstract}

Kesuksesan sistem informasi penerimaan mahasiswa baru sangat diperlukan untuk menunjang segala proses dalam pengolahan data penerimaan mahasiwa baru. Sistem informasi ini dapat diaskses oleh seluruh calon mahasiswa Bina Sarana informatika dimanapun berada dengan syarat adanya koneksi internet. Penelitian ini akan membahas mengenai kesuksesan akan sebuah sistem informasi penerimaan mahasiswa baru. pengukuran kesuksesan suatu sistem informasi sangat dibutuhkan oleh pihak manajemen guna mengetahui nilai tambah bagi peguruan tinggi tersebut [1].

Penelitian menggunakan model keberhasilan sistem informasi yang dikemukakan oleh Delone dan McLean [2]. Dengan enam pengukuran faktor kesuksesan yaitu: Informasi Quality, Service Quality, System Quality, Actual Use, Use Safisfaction, Net Benefit (Individual Impact)[3]. Peranan sistem informasi dalam sebuah organisasi atau perguruan tinggi sudah tidak diragukan lagi, dukungannya dapat membuat sebuah organisasi atau perguruan tinggi memiliki keunggulan kompetitif yang berarti suatu organisasi atau perguruan tinggi dapat bersaing dengan 
organisasi atau perguruan tinggi lainnya dengan mempergunakan sistem informasi [4]

Secara sederhana sistem dapat diartikan sebagai suatu kumpulan atau himpunan dari unsur, komponen, atau variabel yang terorganisasi, saling berinteraksi, saling tergantung satu sama lain dan terpadu [5].

Sistem Informasi merupakan bagian dari empat bagian utama. Keempat bagian utama mencakup perangkat lunak (software), perangkat keras (hardware), infrastruktur, dan Sumber Daya Manusia (SDM) yang terlatih" [6].

Android adalah sistem operasi disematkan pada gadget, baik itu handphone atau tablet, juga sekarang sudah merambah ke kamera digital dan jam tangan [7]. Sejak diakusisi oleh google pada agustus 2005 silam. Android berkembang dengan sangat pesat. Bahkan dalam beberapa tahun terakhir, android berhasil menjadi sistem operasi yang paling banyak digunakan. Hal ini dipicu juga karena semakin banyak vendor smartphone yang mengadopsi sistem operasi android di dalam berbagai produk yang dilemparnya ke pasar [8].

Prosedur PMB Bina Sarana Informatika

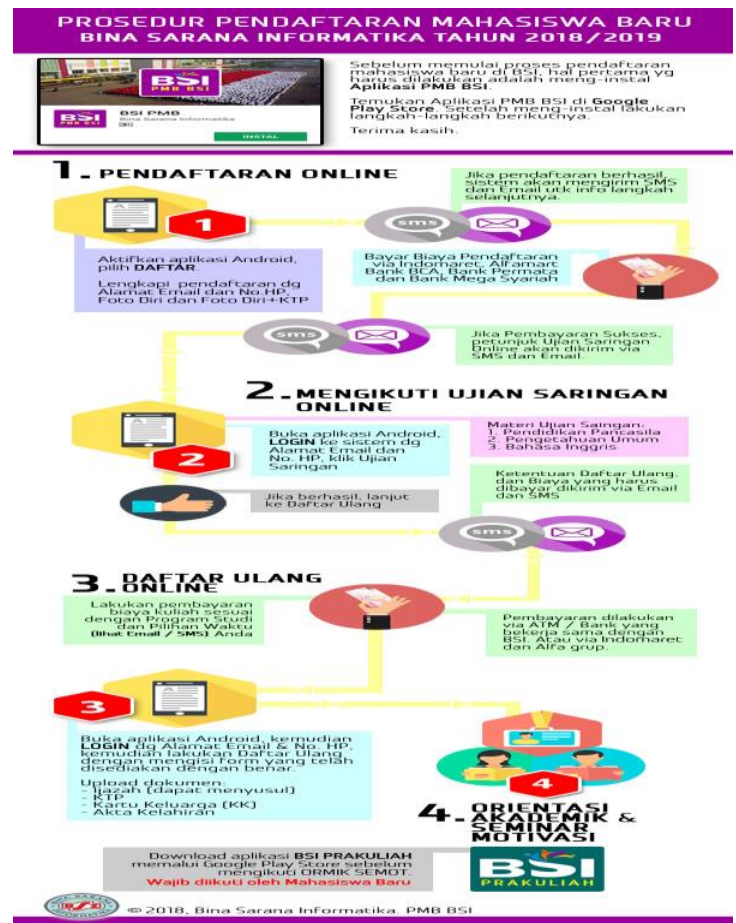

Gambar 1. Prosedur Penerimaan Mahasiswa Baru Sumber : https://pmb.bsi.ac.id/pmb2018/

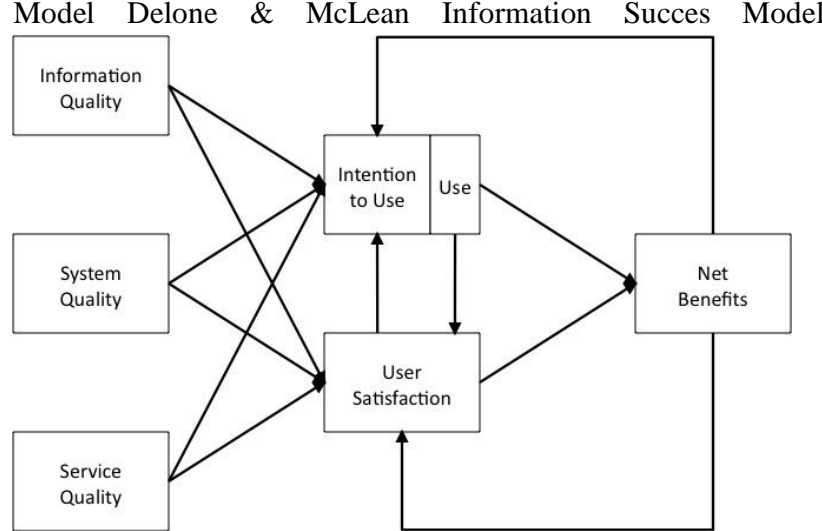

Gambar 2. Updated D\&M IS Success Model

Sumber : [9]

Keterangan :

Kualitas Informasi (Information Quality)

merupakan sebuah output yang berupa informasi dari sistem informasi yang digunakan.

Kualitas Sistem (System Quality)

merupakan kombinasi dari hardware dan software yang digunakan pada sistem informasi.

Kualitas Layanan (Service Quality)

merupakan langkah-langkah pelayanan yang disajikan pada sistem informasi PMB sebagai bentuk wujud pengukuran dari kesuksesan sistem informasi dari sudut pandang calon mahasiswa sebagai pengguna sistem informasi PMB.

Intensitas Penggunaan (Intensity of Use)

Merupakan besarnya frekuensi penggunanaan sistem informasi oleh pengguna.

Kepuasaan Pengguna (User Satisfaction)

Merupakan bentuk respon muncul dari pengguna pada saat setelah selesai menggunakan sistem informasi.

Net Benefits (Individual Impact)

Individual impact dalam model DeLone \& McLean menerangkan mengenai pengaruh dan penggunaan sistem informasi terhadap kualitas kinerja dari pengguna secara individual, yang meliputi produktivitas, efisiensi, dan efektivitas kinerja.

"SPPS merupakan salah satu software statistik yang paling pupoler digunakan di Indonesia. Para pengguna atau user lebih memilih SPSS karena selaian bahasa SPSS yang cepat dan mudah dipahami juga tampilan outputnya terkesan lebih cantik." [10].

\section{METHOD}

Metode penelitian pada dasarnya merupakan cara ilmiah untuk mendapatkan data dengan tujuan dan kegunaan tertentu. terdapat empat kata kunci yang perlu diperhatikan yaitu cara ilmiah, data, tujuan dan kegunaan tertentu [11].

Variabel Penelitian

Variabel penelitian adalah segala sesuatu yang berbentuk apa saja yang ditetapkan oleh peneliti untuk dipelajari sehingga diperoleh informasi tentang hal tersebut, kemudian ditarik kesimpulannya[12].

Berdasarkan pengertian-pengertian diatas, maka dapat dirumuskan disini bahwa variabel penelitian merupakan suatu atribut atau sifat atau nilai dari orang, obyek, atau kegiatan yang 
mempunyai variasi tertentu yang ditetapkan oleh peneliti untuk dipelajari dan kemudian ditarik kesimpulannya.

\section{Skala Pengukuran}

"maksud dari skala pengukuran ini untuk mengklafikasikan variabel yang akan diukur agar tidak terjadi kesalahan dalam menentukan analisis data dan langkah penelitian selanjutnya". Skala yang digunakan dalam penelitian ini adalah skala linkert [13].

"Skala ini digunakan untuk mengukur sikap, pendapat, dan persepsi seseorang atau sekelompok orang tentang variabel penelitian. Dengan skala ini variabel yang diukur dijabarkan menjadi indikator variabel" [14].

Untuk menguji kelayakan data yang didapat dari penyebaran kuisioner dilakukan dua pengujian antara lain :

Uji Validitas

"Validitas di definisikan sejauh mana ketepatan dan kecermatan suatu instrumen pengukur (test) dalam melakukan fungsi ukurnya. Apabila data tidak valid, maka perlu ditinjau ulang pada penyusunan kuisioner" [15].

Uji Reabilitas

Instrumen yang digunakan dalam penelitian ini adalah kuesioner. "Reabilitas merupakan alat untuk mengukur konsistensi data kuisioner yang merupakan indikator dari variabel" [16].

Populasi dan Sample

"Populasi merupakan wilayah dari suatu objek penelitian yang memiliki kualitas dan karateristik yang di tetapkan peneliti untuk dipelajari dan diambil kesimpulan.”[12].

"sampel merupakan bagian dari karakteristik dan jumlah populasi" [12].

Instrumen Penelitian

"Instrumen Penelitian merupakan alat bantu peneliti dalam pen gumpulan data. Mutu instrumen akan menentukan juga mutu daripada data yang dikumpulkan, sehingga tepatlah dikatakan bahwa hubungan instrumen dengan data adalah jantungnya penelitian" [13].

Metode penelitian yang penulis lakukan yaitu:

Metode pengumpulan data yang terdiri dari Penyebaran quisione, observasi dan studi pustaka. Sedangan untuk tahap penyelesaian penelitian dengan menggunakan model Delone dan McLean dengan cara melakukan uji validitas dan reabilitas.

Tabel 1. Variabel dan Indikator Penelitian

\begin{tabular}{|c|c|c|}
\hline $\begin{array}{c}\text { Variabel } \\
\text { penelitian }\end{array}$ & $\begin{array}{l}\text { Indikator } \\
\text { penelitian }\end{array}$ & Penjelasan \\
\hline \multirow{4}{*}{$\begin{array}{l}\text { Information } \\
\text { Quality }\end{array}$} & $\begin{array}{l}\text { Understandability } \\
/ \quad \text { Kemudahan } \\
\text { pemahanan }\end{array}$ & $\begin{array}{l}\text { Apakah informasi yang } \\
\text { diberikan di Aplikasi } \\
\text { PMB mudah dipahami }\end{array}$ \\
\hline & $\begin{array}{l}\text { Completeness } \\
\text { Kelengkapan }\end{array}$ & 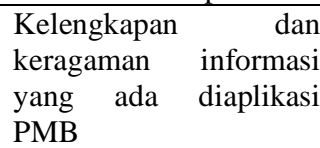 \\
\hline & $\begin{array}{l}\text { Accuracy } \\
\text { Keakuratan } \\
\text { informasi }\end{array}$ & $\begin{array}{l}\text { Informasi harus akurat } \\
\text { dan tidak menyesatkan } \\
\text { agar tidak merusak } \\
\text { informasi yang diterima } \\
\text { pengguna aplikasi PMB } \\
\text { sebagai pengguna }\end{array}$ \\
\hline & $\begin{array}{l}\text { Conciseness } / \\
\text { Keringkasan yang } \\
\text { padat dan jelas }\end{array}$ & $\begin{array}{l}\text { Penjelasan yang ada di } \\
\text { aplikasi PMB dibuat } \\
\text { secara singkat, namun }\end{array}$ \\
\hline
\end{tabular}

\begin{tabular}{|c|c|c|}
\hline $\begin{array}{l}\text { Variabel } \\
\text { penelitian }\end{array}$ & $\begin{array}{l}\text { Indikator } \\
\text { penelitian }\end{array}$ & Penjelasan \\
\hline & isinya & $\begin{array}{lr}\begin{array}{l}\text { komprehensif } \\
\text { lingkup; } \\
\text { singkat }\end{array} & \text { ringkas; } \\
\end{array}$ \\
\hline & $\begin{array}{l}\text { Format } \\
\text { Penyajian } \\
\text { informasi } \\
\end{array}$ & $\begin{array}{l}\text { Informasi di Aplikasi } \\
\text { PMB tersusun sesuai } \\
\text { format }\end{array}$ \\
\hline \multirow{6}{*}{$\begin{array}{l}\text { Service } \\
\text { Quality }\end{array}$} & $\begin{array}{l}\text { Assurance } \\
\text { Jaminan }\end{array}$ & $\begin{array}{lr}\text { Jaminan } & \text { kepercayaan } \\
\text { pengguna } & \text { terhadap } \\
\text { pelayanan } & \text { yang } \\
\text { diperbaiki } & \text { oleh } \\
\text { pengembang } & \text { aplikasi } \\
\text { PMB } & \\
\end{array}$ \\
\hline & $\begin{array}{l}\text { Flexibility/ } \\
\text { Keluwesan }\end{array}$ & $\begin{array}{l}\text { Flexibilitas respon } \\
\text { terhadap perubahan } \\
\text { lingkungan yang sedang } \\
\text { berlangsung }\end{array}$ \\
\hline & $\begin{array}{l}\text { Responsiveness } \\
\text { Daya tanggap }\end{array}$ & $\begin{array}{ll}\text { Ketanggapan layanan } \\
\text { dari pengembang } \\
\text { aplikasi PMB } & \text { terhadap } \\
\text { pengguna } & \text { Aplikasi }\end{array}$ \\
\hline & & $\begin{array}{l}\text { PMB sebagai user } \\
\text { pengguna }\end{array}$ \\
\hline & $\begin{array}{l}\text { Reliability } \\
\text { Keandalan }\end{array}$ & $\begin{array}{l}\text { Kemampuan dari } \\
\text { pengembang aplikasi } \\
\text { PMB memberikan } \\
\text { keandalan apa yang } \\
\text { telah dijanjikan }\end{array}$ \\
\hline & $\begin{array}{l}\text { Tangibles } \\
\text { Tampilan }\end{array}$ & $\begin{array}{l}\text { Tampilan fisik dari } \\
\text { aplikasi PMB yang } \\
\text { diberikan pengembang }\end{array}$ \\
\hline \multirow{5}{*}{$\begin{array}{l}\text { System } \\
\text { Quality }\end{array}$} & Access / Akses & $\begin{array}{lr}\begin{array}{l}\text { Kemudahan } \\
\text { mengakses } \\
\text { PMB }\end{array} & \text { uplikasi } \\
\end{array}$ \\
\hline & $\begin{array}{l}\text { Ease of use / } \\
\text { kemudahan } \\
\text { penggunaan }\end{array}$ & $\begin{array}{lr}\text { Kemudahan } & \text { untuk } \\
\text { pengguna } & \text { dalam } \\
\text { menggunakan } & \text { aplikasi } \\
\text { PMB } & \\
\end{array}$ \\
\hline & $\begin{array}{l}\text { Effeciency } \\
\text { Efisiensi }\end{array}$ & $\begin{array}{lr}\text { Efisiensi } & \text { dari } \\
\text { penggunaan } & \text { sistem } \\
\text { aplikasi PMB } & \text { oleh } \\
\text { pengguna } & \end{array}$ \\
\hline & $\begin{array}{l}\text { Navigation } \\
\text { navigasi }\end{array}$ & $\begin{array}{l}\text { Kemudahan aplikasi } \\
\text { PMB saat dinavigasikan } \\
\text { oleh driver }\end{array}$ \\
\hline & $\begin{array}{l}\text { Respon time / } \\
\text { Waktu respon }\end{array}$ & $\begin{array}{ll}\text { Kecepatan } & \text { waktu } \\
\text { respon aplikasi } & \text { PMB } \\
\text { saat digunakan } & \end{array}$ \\
\hline \multirow[b]{2}{*}{ Actual Use } & $\begin{array}{l}\text { Navigation } \\
\text { patterns / Pola } \\
\text { penggunaan }\end{array}$ & $\begin{array}{lr}\text { Pola pengguna dalam } \\
\text { menggunakan } & \text { dala } \\
\text { mengakses } & \text { apliaksi } \\
\text { PMB } & \\
\end{array}$ \\
\hline & $\begin{array}{l}\text { Nature of use I } \\
\text { Sifat penggunaan }\end{array}$ & $\begin{array}{lr}\text { Sifat dari } & \text { penggunaan } \\
\text { aplikasi } & \text { PMB oleh } \\
\text { pengguna } & \text { dalam } \\
\text { mengakses } & \text { aplikasi } \\
\text { PMB } & \\
\end{array}$ \\
\hline \multirow{2}{*}{$\begin{array}{c}\text { User } \\
\text { Satisfaction }\end{array}$} & $\begin{array}{l}\text { Effectiveness } \\
\text { Efektivitas }\end{array}$ & $\begin{array}{lr}\text { Keefektivitasan } & \text { dari } \\
\text { penggunaan } & \text { sistem } \\
\text { aplikasi PMB yang } \\
\text { memberikan dampak } \\
\text { pada pengguna }\end{array}$ \\
\hline & $\begin{array}{l}\text { Information } \\
\text { satisfaction / } \\
\text { Kepuasan dalam } \\
\text { mendapatkan } \\
\text { informasi }\end{array}$ & $\begin{array}{l}\text { Kepuasan pengguna } \\
\text { dalam mendapatkan } \\
\text { informasi yang didapat } \\
\text { diaplikasi PMB }\end{array}$ \\
\hline
\end{tabular}

DOI: https://doi.org/10.30743/infotekjar.v3i2.1008 


\begin{tabular}{|c|c|c|}
\hline $\begin{array}{l}\text { Variabel } \\
\text { penelitian }\end{array}$ & $\begin{array}{l}\text { Indikator } \\
\text { penelitian }\end{array}$ & Penjelasan \\
\hline & $\begin{array}{l}\text { Overall } \\
\text { satisfaction } \\
\text { kepuasaan secar } \\
\text { keseluruhan }\end{array}$ & $\begin{array}{ll}\text { / Kepuasaan } & \begin{array}{l}\text { pengguna } \\
\text { dalam keseluruhan } \\
\text { a }\end{array} \\
\text { aplikasi PMB }\end{array}$ \\
\hline & $\begin{array}{l}\text { System } \\
\text { satisfaction } \\
\text { kepuasaan sistem }\end{array}$ & $\begin{array}{l}\text { Kepuasaan pengguna } \\
\text { dalam menggunakan } \\
\text { sistem aplikasi PMB } \\
\text { saat ini }\end{array}$ \\
\hline \multirow{4}{*}{$\begin{array}{l}\text { Net benefit } \\
\text { (individual } \\
\text { impact) }\end{array}$} & $\begin{array}{l}\text { Decision } \\
\text { Effectiveness } \\
\text { Efektivitas } \\
\text { keputusan }\end{array}$ & $\begin{array}{lr}\text { Keefektivitasan } & \text { dari } \\
\text { penggunaan } & \text { sistem } \\
\text { aplikasi PMB } & \text { oleh } \\
\text { pengguna } & \\
\end{array}$ \\
\hline & $\begin{array}{l}\text { Individual } \\
\text { produktivitas }\end{array}$ & $\begin{array}{l}\text { Aplikasi PMB dapat } \\
\text { membantu produktivitas } \\
\text { pengguna }\end{array}$ \\
\hline & $\begin{array}{l}\text { Learning } \\
\text { pembelajaran }\end{array}$ & $\begin{array}{lr}\text { Pengguna } & \text { dapat } \\
\text { melakukan } & \\
\text { pembelajaran } & \text { yang } \\
\text { lebih banyak } & \text { dengan } \\
\text { menggunakan } & \text { aplikasi } \\
& \text { PMB }\end{array}$ \\
\hline & $\begin{array}{l}\text { Usefulness } \\
\text { Kegunaan }\end{array}$ & $\begin{array}{l}\text { Aplikasi } \quad \text { PMB } \\
\text { memberikan kegunaan } \\
\text { yang signifikan kepada } \\
\text { pengguna }\end{array}$ \\
\hline
\end{tabular}

\section{RESULTS AND DISCUSSION}

\section{Populasi dan Sampel}

Populasi didapat dari semua mahasiswa baru fakultas ekonomi dan bisnis program studi Administrasi Bisnis dan Admministrasi perkantoran pada Universitas Bina Sarana Informatika kampus jatiwariangin. Mahasiswa tersebut sudah melakukan penggunaan apliaksi tersebut pada saat melakukan proses pendaftaran dan proses mengerjakan ujian saringan. Pengambilan sampel penelitian ini menggunakan teknik kepada seluruh mahasiswa pada program study tersebut. Dengan total jumlah sebanyak 133 mahasiswa dan semua pengisian lengkap dan dapat diolah

$\mathrm{n}=\frac{\mathrm{N}}{1+\mathrm{N} \mathrm{d}^{2}}$

Keterangan :

$\mathrm{n} \quad=$ Jumlah minimum responden

$\mathrm{N}=$ Ukuran Populasi

$\mathrm{d} \quad=$ Error yang digunakan

$\mathrm{n}=\frac{\mathrm{N}}{1+\mathrm{N} \mathrm{d}^{2}} \cdots \cdots$

$\mathrm{n}=\frac{133}{1+133(0,05)^{2}}$

$\mathrm{n}=\frac{133}{1+133(0,0025)}$

$\mathrm{n}=\frac{133}{1+0,3325}=\frac{133}{1,3325}=\mathbf{9 9 , 8}$

Dalam penelitian ini acceptable error (tingkat kesalahan) yang digunakan adalah 5\%. Dari hasil yang dapat dilihat pada perhitungan di atas, didapati sampel minimum yaitu sebanyak 99,8 dan diambil sampel sebanyak 100 responden. Sehingga penulis dapat menganalisa tentang layanan aplikasi yang Rincian penyebaran sampel penelitian dapat dilihat dalam tabel di bawah ini :
Tabel 2. Populasi dan Sampel Penelitian

\begin{tabular}{|c|c|c|c|}
\hline No. & Sumber Data & $\begin{array}{l}\text { Jumlah } \\
\text { Populasi }\end{array}$ & $\begin{array}{l}\text { Jumlah } \\
\text { Sampel }\end{array}$ \\
\hline 1 & Administasi Bisnis (D3) & 109 & 109 \\
\hline 2 & $\begin{array}{l}\text { Administrasi } \\
\text { (D3) }\end{array}$ & 24 & 24 \\
\hline \multicolumn{2}{|r|}{ Total } & 133 & 133 \\
\hline
\end{tabular}

\section{Responden}

Pada penelitian ini penulis membagikan sebanyak 133 kuesioner. Dimana datanya sebagai berikut kuesioner yang kembali ke peneliti sekitar 133 responden. Karena data-data tersebut, maka peneliti dalam penelitian ini menggunakan 133 responden. Data profil responden yang menjadi obyek dapat dilihat pada tabel sebagai berikut:

Tabel 3. Data Responden

\begin{tabular}{ccc}
\hline Klasifikasi Responden & Jumlah & Presentasee \\
\hline Jenis Kelamin & & \\
- Laki-Laki & 19 & $14,3 \%$ \\
- Perempuan & 114 & $85,7 \%$ \\
\hline Total & 133 & $100 \%$ \\
\hline
\end{tabular}

\section{Uji Validitas}

Uji validitas digunakan untuk mengukur sah atau valid tidaknya suatu kuesioner.suatu kuesioner dikatakan valid jika pertanyaan pada kuesioner mampu mengungkapkan sesuatu yang akan diukur oleh kusioner tersebut [17].

Suatu instrument penelitian dikatakan valid, bila :

a. Koefisien kolerasi product moment melebihi 0,3

b. Koefisien kolerasi product moment $>$ r-tabel $(\alpha, ; n-2) n=$ jumlah sampel.

c. Nilai $\operatorname{sig} \leq \alpha$

Rumus yang bisa digunakan untuk uji validalitas konstruk dengan teknik korelasi product moment, yaitu :

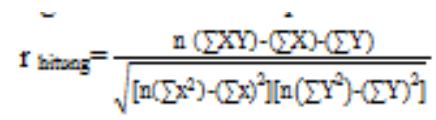

Keterangan:

$\mathrm{n}=$ Jumlah Responden

$\mathrm{x}=$ Skor variabel (jawaban responden

$\mathrm{y}=$ Skor total dari variabel

Menghitung validitas secara manual 
Tabel 4. Data Responden

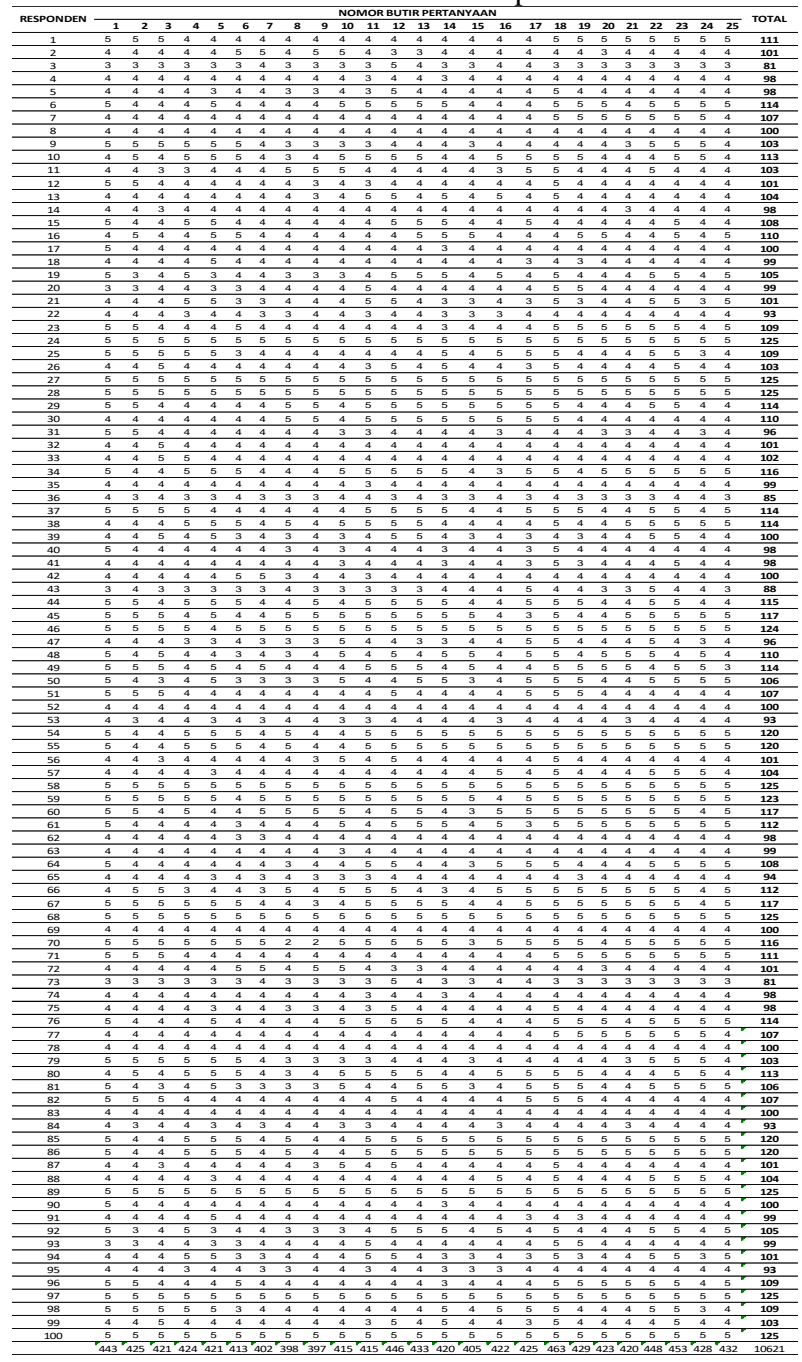

a) Menjumlahkan skor jawaban

Responden $1=111$

b) Uji validitas setiap butih pertanyaan

Pada tahap ini melakukan uji validitas dari setiap butir pertanyaan dengan cara jawaban setiap butir pertanyaan diidentifikasi menjadi variabel $\mathrm{X}$ dan total jawaban menjadi variabel $Y$

c) Mengitung nilai $r$ tabel

$\mathrm{n}=100, \alpha=0,05$

sehinga, nilai $\left.\mathrm{r}_{(0,05}, 100-2\right)$ pada product moment $=$ 0,195

d) Menghitung nilai $\mathrm{r}_{\text {hitung }}$

$$
\begin{aligned}
r_{\text {hitung }} & =\frac{n\left(\sum X Y\right)-\left(\sum X\right)\left(\sum Y\right)}{\sqrt{\left[n\left(\sum x^{2}\right)-\left(\sum x\right)^{2}\right]\left[n\left(\sum Y^{2}\right)-\left(\sum Y\right)^{2}\right]}} \\
& =\frac{41297}{3451} \\
& =\frac{41297}{3473290009} \\
& =\frac{41297}{58934,62487} \\
& =\mathbf{0 , 7 0 1} \\
& =\mathbf{0 0 0 4 5 9}
\end{aligned}
$$

\begin{tabular}{|c|c|c|c|}
\hline No & Dimensi & Rtabel & Rhitung \\
\hline 1 & \multirow{5}{*}{$\begin{array}{c}\text { Information } \\
\text { Quality }\end{array}$} & 0,195 & 0,701 \\
\hline 2 & & 0,195 & 0,654 \\
\hline 3 & & 0,195 & 0,654 \\
\hline 4 & & 0,195 & 0,707 \\
\hline 5 & & 0,195 & 0,667 \\
\hline 6 & \multirow{5}{*}{$\begin{array}{l}\text { Service } \\
\text { Quality }\end{array}$} & 0,195 & 0,563 \\
\hline 7 & & 0,195 & 0,591 \\
\hline 8 & & 0,195 & 0,587 \\
\hline 9 & & 0,195 & 0,528 \\
\hline 10 & & 0,195 & 0,610 \\
\hline 11 & \multirow{5}{*}{$\begin{array}{l}\text { System } \\
\text { Quality }\end{array}$} & 0,195 & 0,745 \\
\hline 12 & & 0,195 & 0,575 \\
\hline 13 & & 0,195 & 0,738 \\
\hline 14 & & 0,195 & 0,686 \\
\hline 15 & & 0,195 & 0,637 \\
\hline 16 & \multirow{2}{*}{ Actual Use } & 0,195 & 0,599 \\
\hline 17 & & 0,195 & 0,564 \\
\hline 18 & \multirow{4}{*}{$\begin{array}{c}\text { User } \\
\text { Satisfaction }\end{array}$} & 0,195 & 0,675 \\
\hline 19 & & 0,195 & 0,731 \\
\hline 20 & & 0,195 & 0,781 \\
\hline 21 & & 0,195 & 0,799 \\
\hline 22 & \multirow{4}{*}{$\begin{array}{c}\text { Net benefit } \\
\text { (individual } \\
\text { impact) }\end{array}$} & 0,195 & 0,697 \\
\hline 23 & & 0,195 & 0,756 \\
\hline 24 & & 0,195 & 0,667 \\
\hline 25 & & 0,195 & 0,750 \\
\hline
\end{tabular}

e) Membuat keputusan

Pertanyaan respondent 1: dinyatakan valid, karena nilai $r_{\text {htiung }}=0,701>r_{\text {tabel }}=$ 0,195

Tabel 5. Menghitung Validitas

Menghitung reliabilitass secara manual pengukuran reabilitas menggunakan teknik Alpha Cronbach. Kriteria suatu instrument penelitian dikatakan reabel dengan menggunakan teknik ini, bila koefisien reabilitas $\left(\mathrm{r}_{11}\right)>0,6$. Tahapan perhitugan uji reliabilitas dengan menggunakan teknik Alpha Cronbach, yaitu:

a. Menghitung varian setiap butir pertanyaan

$$
\alpha_{i}^{2}=\frac{\sum \mathrm{X}_{\mathrm{i}}^{2}-\frac{\left(\sum \dot{\mathrm{X}}_{\mathrm{i}}\right)^{2}}{\mathbf{n}}}{\mathrm{n}}
$$

b. Menghitung nilai varian total

$$
\alpha_{i}^{2}=\frac{\Sigma \mathrm{X}_{\mathrm{i}}^{2}-\frac{\left(\Sigma \mathrm{X}_{\mathrm{i}}\right)^{2}}{\mathrm{n}}}{\mathbf{n}}
$$

c. Menentukan reabilitas instrument

$$
\begin{aligned}
& r_{11} \\
& =\left[\frac{K}{K-1}\right]\left[1-\frac{\sum \alpha_{b}^{2}}{\alpha_{t}^{2}}\right]
\end{aligned}
$$


Tabel 6. Reliability Statistics

Keterangan:

$\mathrm{n} \quad=$ Jumlah sample

$\mathrm{X}_{\mathrm{i}} \quad$ = Jawaban responden

$\sum \mathrm{X}=$ Total jawaban responden

$\alpha_{i}^{2} \quad=$ Varian total

$\alpha_{\mathrm{b}}^{2} \quad=$ Jumlah varian butir

$K \quad=$ Jumlah butir pertanyaan

$r_{11}=$ Koefisien reabilitas instrumen

1) Menghitung reabilitas secara manual

a). Menghitung nilai varian setiap butir pertanyaan Responden 1:

$$
\begin{gathered}
\alpha_{i}^{2}=\frac{\Sigma \mathbf{X}_{\mathrm{i}}^{2}-\frac{\left(\Sigma \mathbf{X}_{\mathrm{i}}\right)^{2}}{\mathbf{n}}}{\mathbf{n}} \\
\alpha_{\mathrm{i}}^{2}=\frac{\mathbf{1 9 9 7 - \frac { ( \mathbf { 4 4 3 } ) ^ { 2 } } { 1 0 0 }}}{\mathbf{1 0 0}} \\
=\frac{1997-\frac{196249}{100}}{100} \\
=\frac{1997-1962,49}{100}=0,345
\end{gathered}
$$

b) Total Nilai Varian Butir

$$
\begin{aligned}
& =0,345+0,368+0,346+0,362+0,486+0,413 \\
& +0,300+0,460+0,409+0,428+0,528+0,328 \\
& +0,301+0,500+0,348+0,312+0,428+0,273 \\
& +0,406+0,317+0,360+0,310+0,289+0,362 \\
& +0,318=9,293
\end{aligned}
$$

c) Nilai Varian Total

$$
\begin{gathered}
\alpha_{\mathrm{T}}^{2}=\frac{\sum X^{2}-\frac{\left(\sum X\right)^{2}}{n}}{n} \\
\alpha_{\mathrm{T}}^{2}=\frac{1138121-\frac{(10621)^{2}}{100}}{100} \\
\alpha_{\mathrm{T}}^{2}=\frac{1138121-1128056,41}{100} \\
\alpha_{\mathrm{T}}^{2}=100,646
\end{gathered}
$$

d) Menghitung nilai reabilitas instrument

$$
\begin{aligned}
& r_{11} \\
& =\left[\frac{K}{K-1}\right]\left[1-\frac{\sum \alpha_{b}^{2}}{\alpha_{t}^{2}}\right\rceil \\
& \quad r_{11}=\left[\frac{100}{100-1}\right]\left[1-\frac{9,292}{100.646}\right] \\
& r_{11}=0,917
\end{aligned}
$$

Instrumen penelitian dinyatakan reliabel, karena nilai $r_{11}=0,917>0,6$

2) Menghitung reabilitas secara SPSS

\begin{tabular}{ll}
\hline Cronbach's Alpha & N of Itens \\
\hline 0,917 & 100 \\
\hline
\end{tabular}

\section{CONCLUSIONS}

Berdasarkan penelitian yang dilakukan didapat hasil bahwa varibel yang dilakukan penelitian yaitu information quality, service quality, system quality, actual use, use satisfaction, net benefit (individual impact) mempunyai keterkaitan antar variabelnya dan mempunyai kualitas yang dapat dipercaya, sistem yang baik, dan layanan yang memuaskan. Sehingga kualitas dari aplikasi PMB tersebut sudah maksimal tetapi perlu adanya perbaikan untuk meningkatkan pelayanan dikarenakan sekarang sudah berubah menjadi Universitas agar dapat bersaing dengan dengan universitas-universitas lainnya.

\section{REFERENCES}

[1] K. Yuliana, "Model Kesuksesan Sistem Informasi Delone Dan Mclean Untuk Evaluasi Sistem Informasi Pos Pada Pt. Pos Indonesia (Persero) Divisi Regional Vi Semarang," Infokam, vol. II, no. Ii, p. 16, 2016.

[2] I. S. Sakkinah and S. Patmanthara, "Analisis keberhasilan sistem e-learning smk negeri 1 malang," Elinvo (Electronics, Informatics, Vocat. Educ., vol. 2, no. 1, pp. 59-63, 2017.

[3] W. H. DeLone and E. R. McLean, "Information systems success: The quest for the dependent variable," Inf. Syst. Res., vol. 3, no. 1, pp. 60-95, 1992.

[4] A. Kadir, Pengenalan Sistem Informasi. Yogyakarta: Andi Yogyakarta, 2014.

[5] T. Sutabri, Konsep Dasar Informasi. Yogyakarta: Andi Offset, 2012.

[6] I. P. A. E. Pratama, Sistem Informasi Dan Implementasinya Berbasis Open Source. Bandung: Informatika, 2014.

[7] A. Wahdoyo, Android 4 untuk Pengguna Pemula Tablet dan Handphone, 1st ed. Jakarta: PT. Transmedia, 2013.

[8] L. F. S. Putri and I. Mahendra, "Analisa Faktor-Faktor Yang Mempengaruhi Penerimaan Dan Penggunaan Aplikasi Go-Jek Menggunakan Unified Theory Of Acceptance And Use Of Technology ( UTAUT )," $J$. Pilar Nusa Mandiri, vol. 13, no. 1, pp. 136-144, 2017.

[9] W. Delone and E. McLean, "the Delone and Mclean model of information sys- tems success: A ten-year update," J. Manag. Inf. Syst., vol. 19, no. 4, p. 9-30., 2003.

[10] G. Pramesti, Kupas Tuntas Data Penelitian dengan SPSS 22. Jakarta: Elex Media Komputindo, 2015.

[11] Sugiyono, Metode Penelitian Kuantitatif, Kualitatif, dan $R \& D$. Bandung: Alfabeta, 2016.

[12] Sugiyono, Metode Penelitian Kuantitatif, Kualitatif, dan R\&D. Bandung: Alfabeta, 2017.

[13] Riduwan, Skala Pengukuran Variabel-Variabel $P$. Bandung: Alfabeta, 2013.

[14] A. Anfina, F. N. Salisah, and I. Permana, "Analisa kesuksesan penerapan sistem perhotelan dengan pendekatan model delone and mclean," J. Ilm. Rekayasa dan Manaj. Sist. Inf., vol. 4, no. 1, pp. 56-59, 2018.

[15] A. Saryoko, "Tingkat Kepuasan Masyarakat Pengguna Aplikasi Go-Jek Menggunakan Motode Servqual," $J$. Sist. Inf. STMIK Antar Bangsa, vol. 5, no. 2, pp. 158- 
$164,2016$.

[16] A. Widodo, "Pengaruh Kualitas Sistem Aplikasi Dan Kualitas Informasi Terhadap Kepuasan Pengguna Sistem Aplikasi Rts (Rail Ticketing System) Dengan Kepercayaan Sebagai Variabel Mediasi," Media Ekon. Dan Manaj., vol. 31, no. 2, pp. 160-181, 2016.

[17] I. Ghozali, Aplikasi Analisis Multivariate dengan program SPSS. Semarang: Badan Penerbit Universitas Diponegoro, 2013.

\section{AUTHOR(S) BIOGRAPHY}

Penulis Pertama

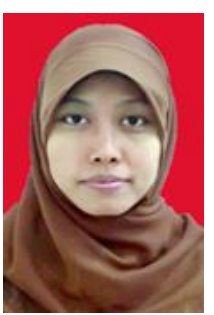

Nani Agustina, Tahun 2009 program S1 STMIK Nusa Mandiri, Tahun 2011 lulus S2 pada Pasca Sarjana Nusa Mandiri Jakarta, dan berkerja pada Universitas Bina Sarana Informatika dapa tahun 2008 sampai dengan sekarang Fakultas Teknologi Informasi.

Penulis Kedua

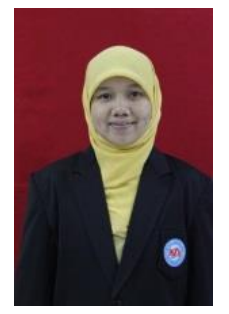

Entin Sutinah, Tahun 2009 lulus dari program starta satu (S1) program studi Sistem Informasi Manajemen STMIK Swadharma Jakarta, Tahun 2014 Lulus dari program starata dua (S2) program studi Ilmu Komputer STMIK Nusa Mandiri Jakarta. saat ini berkerja sebagai staff pengajar di Universitas Bina Sarana Informatika Fakltas Kenologi

Informasi. 